\title{
ADDITIONAL DATA ON LEPIDOPTERA FROM SERBIA
}

\author{
PREDRAG JAKŠIĆć ${ }^{1, \star}$ \\ ${ }^{1}$ Faculty of Natural Sciences and Mathematics, University of Priština, Kosovska Mitrovica, Serbia
}

\begin{abstract}
This work reports on results from occasional collections in many sites of Serbia in the period 2015-2018., as well as one earlier material from 1982. By more than 50 excursions, from March to October, by day and night and by light traps, a total amount of $\mathbf{4 5}$ selected species of Lepidoptera from $\mathbf{1 0}$ families were caught. A full list and description of the localities of collection, some colour plates and the comment about some species apart relevant are also included.
\end{abstract}

Keywords: Lepidoptera, Serbia

\section{INTRODUCTION}

During the few last decades our knowledge of the Lepidoptera fauna of Serbia has significantly increased. The most notable contributions are by Jakšić (2016b) for Serbian „Microlepidoptera",Vasić (2002) and Beshkov (2015) for Serbian Noctuidae, Tomić et al. (2002) and Dodok (2006) for Serbian Geometridae, as well as Stojanović (2012) and Vajgand (2012) for Vojvodina, also Beshkov (2015, 2017),Plant et al. (2017) and Jakšić (2017) for eastern Serbia. Still, a significant part of territory of Serbia remain with only few historical or recent publications. The researchers attention was focused on new species for Serbian fauna. On the other hand, data on "ordinary" species are insufficient.

The goal of this paper is to improve our knowledge about distribution of Lepidoptera species in Serbia. Besides, all available literature and collection data were taken into account.

\section{MATERIALS AND METHODS}

To gain an overview of the knowledge of the Lepidoptera fauna of Serbia all the available literature was consulted.

Specimens were collected with entomological net and light trap, using Mercury vapor bulb $125 \mathrm{~W}$. The positions and coordinates at which the Lepidoptera were caught were determined using Garmin e-Trex 10 Vista GPS device. The following sites were in-

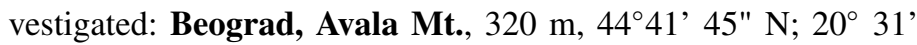
04" E; Beograd, Zvezdara, $187 \mathrm{~m}, 44^{\circ} 47^{\prime} 53^{\prime \prime} \mathrm{N}$; 20 $30^{\circ}$ ' $18^{\prime \prime}$ E; 113-122, 8 figs, $80 \mathrm{~m}, 44^{\circ} 48^{\prime} 58^{\prime \prime} \mathrm{N}$; 20 26' $02^{\prime \prime} \mathrm{E}$; Zlatibor Mt., vic. Ljubiš village, 1105 m, 43 $37^{\circ} 42^{\prime \prime} \mathrm{N}$; $19^{\circ} 45^{\prime} 24^{\prime \prime} \mathrm{E}$; Kovin, vic. Dubovac village, $70 \mathrm{~m}, 44^{\circ} 47^{\prime} 36^{\prime \prime} \mathrm{N} ; 21^{\circ} 12^{\prime} 25^{\prime \prime}$ E; Bela Palanka, Šljivovički Vis Mt., 926 m, 43 $08^{\prime} 28^{\prime \prime} \mathrm{N} ; 22^{\circ}$

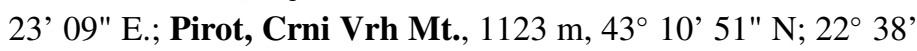
52" E; Svrljig, Tresibaba Mt., 700 m, , 43 30' 14" N; 22 $12^{\circ}$ '

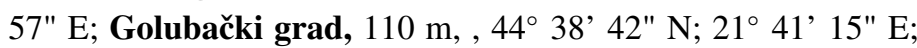
Novo Brdo, Bostane village, $800 \mathrm{~m}$, 46 $36^{\circ} 02^{\prime \prime} \mathrm{N}$; $21^{\circ} 25^{\prime} 40^{\prime \prime}$ E; Divčibare vic. Kaona, 829 m, , 44 06’ 39" N; $19^{\circ} 56^{\prime} 17^{\prime \prime} \mathrm{E}$;

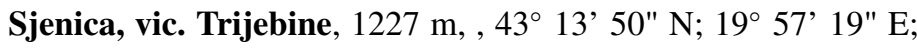
Niš, Jelašnička Klisura Gorge, 442 m, , 43 16' 05" N; 22 $04^{\circ}$ '
16" E; Suva Planina Mt., Bojanine Vode, $1000 \mathrm{~m}, 43^{\circ} 13^{\prime} 22^{\prime \prime}$ $\mathrm{N}$; $22^{\circ} 06^{\prime}$ 54" E; Gornje Kusce village, Gnjilane, $580 \mathrm{~m}, 42^{\circ}$ 29' 57" N; 21 29' 00" E and Zubin Potok, Velji Breg, 600 m, $42^{\circ} 55^{\prime} 51^{\prime \prime} \mathrm{N} ; 20^{\circ} 40^{\prime} 38^{\prime \prime} \mathrm{E}$;

After preparing, we determined the specimens by the wingpatterns and in all cases the identification has been also carried out by an examination of the male genitalia. The preparations were carried out following the well known standard procedure: maceration by boiling in potash, dissecting and cleaning, clearing in xylolum and mounting in Canada balsam. The photos of genital parameters were taken using the "Nikon SMZ800N" microscope with compact PC-based camera.

Fieldwork on protected areas was done on the basis of permits provided by the Ministry of Environment, Mining and Spatial Planning, Republic of Serbia, No. 353-01-389/2016-17, dated from 8. 4. 2016. and No. 353-01-834/2017-17, dated from 11. 05. 2017.

All the material (specimens and genitalia slides) is deposited in the author's collection.

The taxonomic order and nomenclature follows Fibiger et al. (2011) for Noctuidae and Aarvik et al. (2017) for other Lepidoptera. ID number before the species follows Karsholt \& Razowski (1996).

\section{RESULTS AND DISCUSSION}

Altogether 45 species were recorded. We present and discuss the results by taxonomic order.

Ordo Lepidoptera Linnaeus, 1758

Superfam. Tortricoidea Latreille, 1802

Fam. Tortricidae Latreille, 1803

Subfam. Olethreutinae Walsingham, 1895

4731 Celypha lacunana ([Denis \& Schiffermüller], 1775)

Material examined: Beograd, Avala Mt., 320 m: 1 m, 28. V 2017. Observed and photo (Fig. 1.) by Jakšić P. The larva feeds on Vaccinium myrtillus and Lycophotia porphyrea. New species for Serbia.

\footnotetext{
^ Corresponding author: jaksicpredrag@ gmail.com
} 


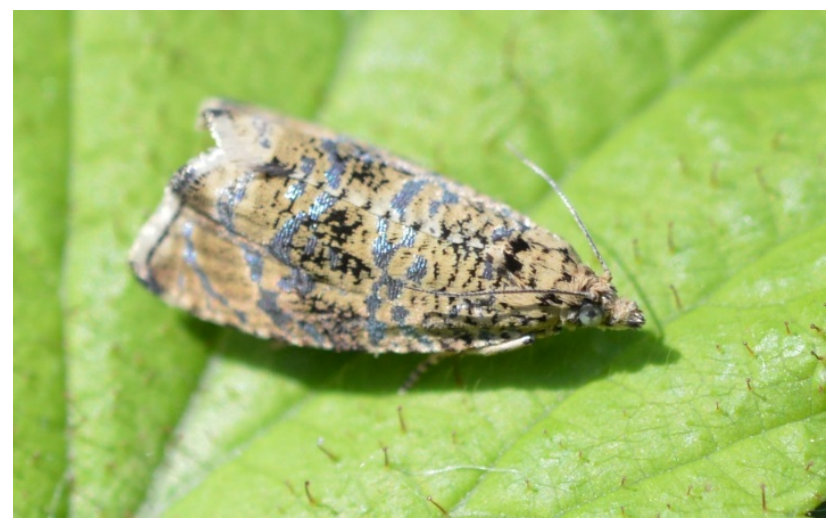

Figure 1. Celypha lacunana ([Denis \& Schiffermüller], 1775). Photo Jakšić P.

\section{Superfam. Cossoidea Leach, 1815}

Fam. Cosiidae Leach, 1815

4166 Dyspessa ulula (Borkhausen, 1790)

Material examined: Pirot, Crni Vrh,1123 m: 1 f, 20. V 2017. Bela Palanka, Šljivovički vis, 926 m: 2 m 2 f, 22 . VI 2017.

Larval foodplants are Allium species, Marković (2014) reported eight species from this genus on Vidlič Mt.

Superfam. Gelechioidea Stainton, 1854

Fam. Lypusidae Herrich-Schäffer, 1857

Subfam. Chimabachinae Heinemann, 1870

2231 Diurnea fagella ([Denis \& Schiffermüller], 1775)

Material examined: Beograd, Avala Mt., 320 m: 1 m, 2. IV 2017. Genitalia checked, slide SR-2936.; Gnjilane, Gornje Kusce, 550 m, 1 m, 24. III 2018., Janićijević T. leg., Jakšić P. coll.; Zubin Potok, Velji Breg, 630 m, 1 m, 14. IV 2018., Živković M. leg., Jakšić P. coll.

The larvae feed on various deciduous trees, such as Quercus and Betula.

Superfam. Papilionoidea Latreille, 1802

Fam. Lycaenidae Leach, 1815

7129 Plebejus argyrognomon (Bergsträsser, 1779)

Material examined: Niš, Jelašnička Klisura Gorge 450 m: 1 f, 12. V 2015. Photo Jakšić P.

This meso-xerophile species occur on calcareous habitat, such is Jelašnica gorge. Larval food plant is Securigera varia.

7171 Polyommatus daphnis ([Denis \& Schiffermüller], 1775)

Material examined: Svrljig, Tresibaba Mt., 700 m: 1 f, 14. VI 2017. Observed and photo by Jakšić P. Monophage caterpillars feed on Securigera varia.

\section{Fam. Nymphalidae Rafinesque, 1815}

7312 Lasiommata maera (Linnaeus, 1758)

Material examined: Golubački Grad, 110 m: $1 \mathrm{~m}, 30$. VII 2016. Genitalia checked, slide SR-2687 (Fig. 4).

The larva eats full-grown grasses, from the genus Poa, Festuca, Glyceria, Calamagrostis, Deschampsia, Agrostis, Nardus, Dactylis, Lolium and Hordeum species.

Superfam. Pyraloidea Latreille, 1809

Fam. Crambidae Latreille, 1809

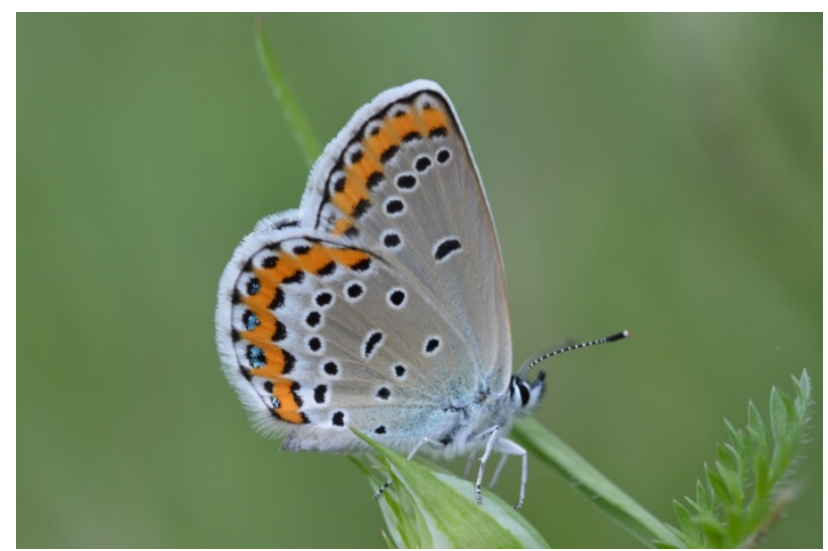

Figure 2. Plebejus argyrognomon (Bergsträsser, 1779). Photo Jakšić P.

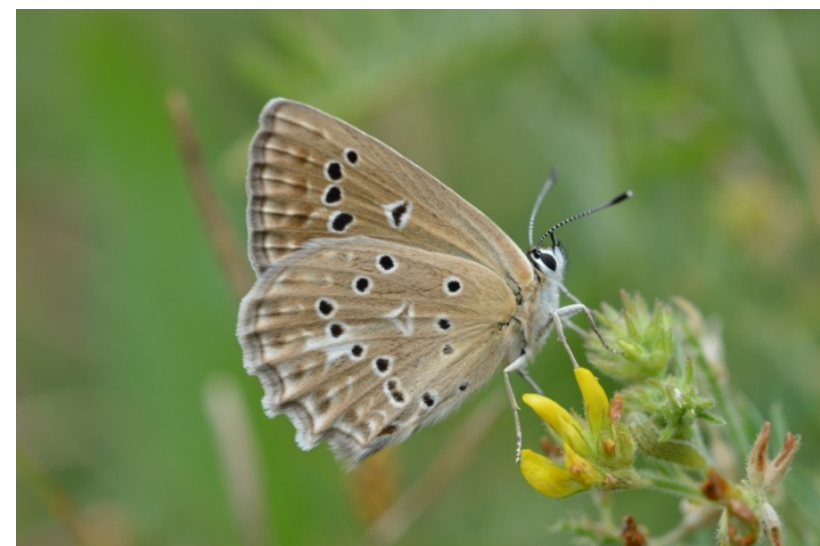

Figure 3. Polyommatus daphnis ([Denis \& Schiffermüller], 1775). Photo Jakšić P.

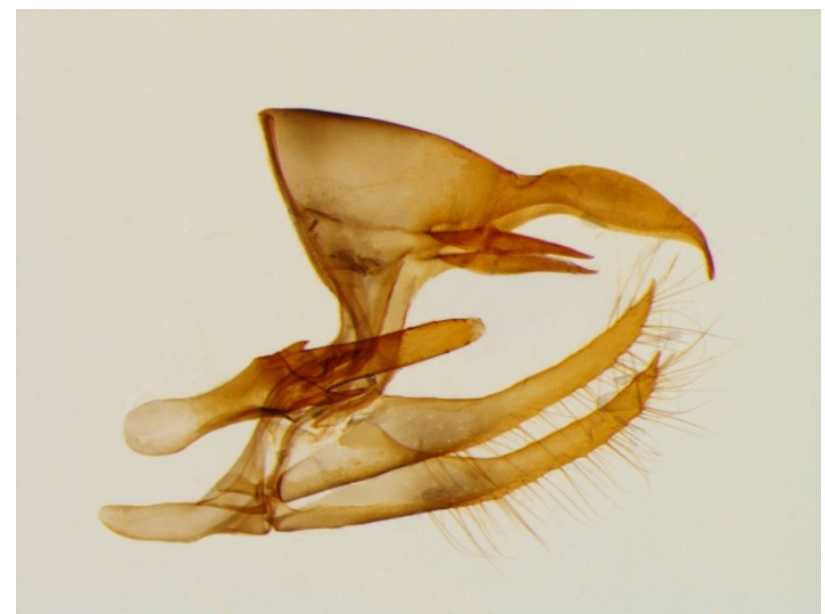

Figure 4. Lasiommata maera (Linnaeus, 1758), male genitalia.

6478 Eurrhypis pollinalis ([Denis \& Schiffermüller], 1775)

A survey of the literature: Plant et al. (2017) has identified this species on Mt. Šljivovički Vis. Material examined: Svrljig, Tresibaba Mt., 700 m: 2 m 1 f, 14. VI 2017. Observed and photo (Fig. 5) by Jakšić P. 
The caterpillars feed on Genista, Glycirrhiza, Laburnum, Cytisus and Ononis species.

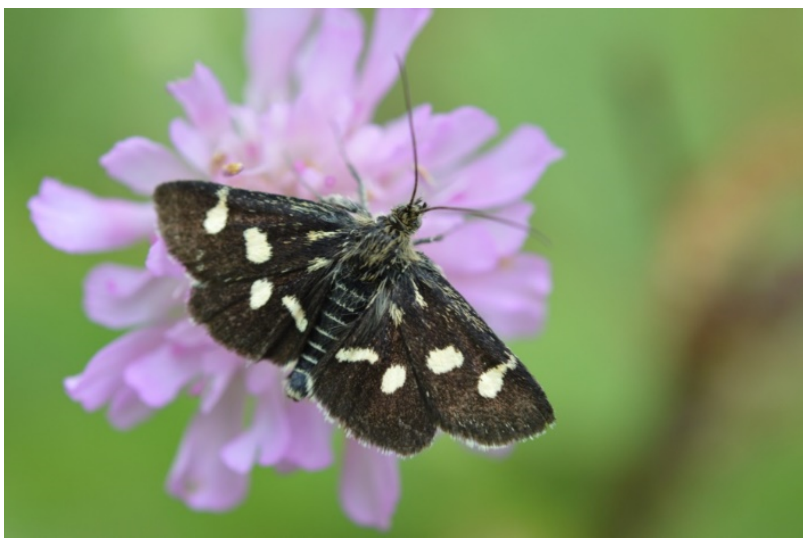

Figure 5. Eurrhypis pollinalis ([Denis \& Schiffermüller], 1775). Photo Jakšić P.

\section{Pyrausta aurata (Scopoli, 1763)}

A survey of the literature: Common species, Rotschild (1912-1917) on Deliblato Sands; Plant et al. (2017) has identified this species on several localities: Pirot, Crni Vrh; Pčinja, Vražiji Kamen; Preševo, Trnava; and Bela Palanka, Šljivovički Vis. Material examined: Beograd, Avala Mt., 312 m: 1 m 1 f, 2. IV 2017, 1 m, 11. IV 2017.; 1 m, 26. IV 2017 (Fig. 6).

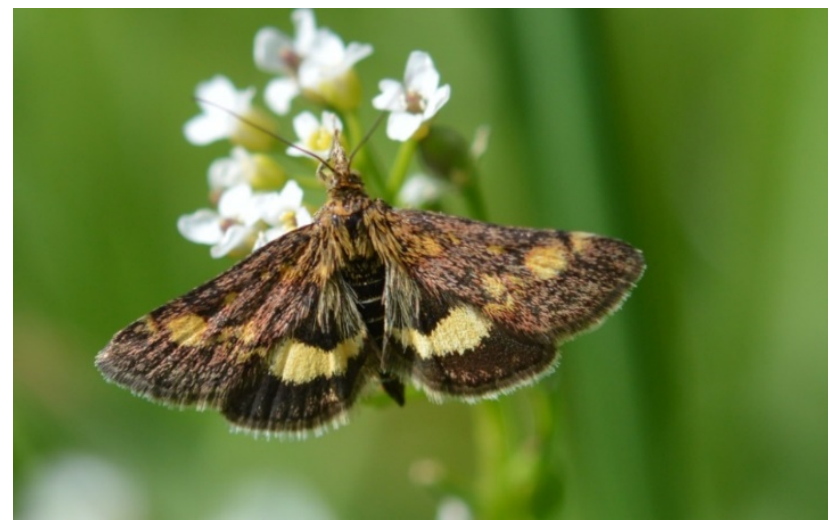

Figure 6. Pyrausta aurata (Scopoli, 1763). Avala Mt. Photo Jakšić P.

\section{Superfam. Geometroidea Leach, 1815 \\ Fam. Geometridae Leach, 1815}

7527 Lomaspilis marginata (Linnaeus, 1758)

Material examined: Kovin, Dubovac, 75 m: $1 \mathrm{~m}, 8$. VII 2016. Genitalia checked, slide SR-2933 (Fig. 7). The larvae feed on Salix and Populus, especially P. tremula.

7559 Narraga tessularia (Metzner, 1845)

A survey of the literature: Beshkov (2015) and Jakšić (2017). Both authors independently found this species in the same locality on Pirot, Crni Vrh Mt.

Material examined: Pirot, Crni Vrh Mt., 1123 m: common, 20-21. VI 2017.; Bela Palanka, Šljivovički vis, 926 m: common. Genitalia checked, slide SR-2918. Šljivovički Vis Mt. is the sec-

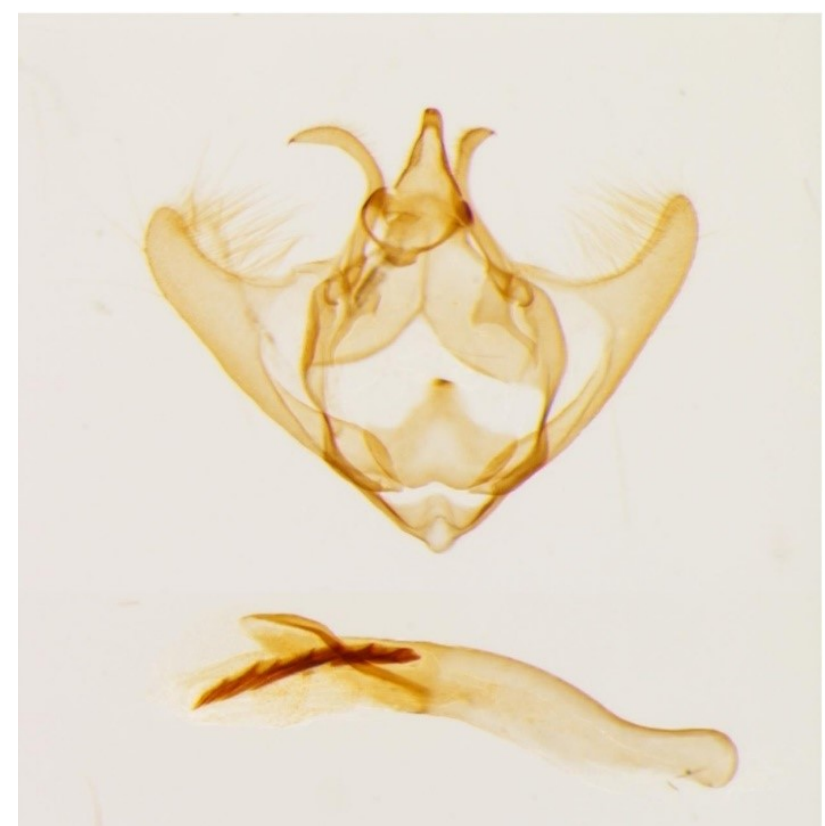

Figure 7. Lomaspilis marginata (Linnaeus, 1758), male genitalia, slide SR-2933.

ond locality on which this species has been established (Fig. 8). Ecologicaly, it is a specialist of salty steppes with Artemisia maritima as a larval food plant. In eastern Serbia it is locally distributed in the forest belt, up to $1000 \mathrm{~m}$ above sea level, occurring in forest margins. On so far known habitats in eastern Serbia Artemisia alba Turra were present. This means that the habitat shift has occurred. This is a taxon with a disjunct distribution. It is distributed in Iberian Peninsula (Granada), South-East Europe and central Asia (Russia, Kazakhstan). Agenjo (1956) described this species as a N. isabel Agenjo, 1956. Now, this name is synonym. Several subspecies are described: N. t. tessularia (Metzner, 1845); N. t. illia Wehrli, 1940; N. t. kasyi Moucha \& Povolny, 1957 and N. t. pannonica Vojnits, 1977. According to Skou \& Sihvonen (2015) populations from Serbia are related to nominal subspecies - N. tessularia tessularia (Metzner, 1845).

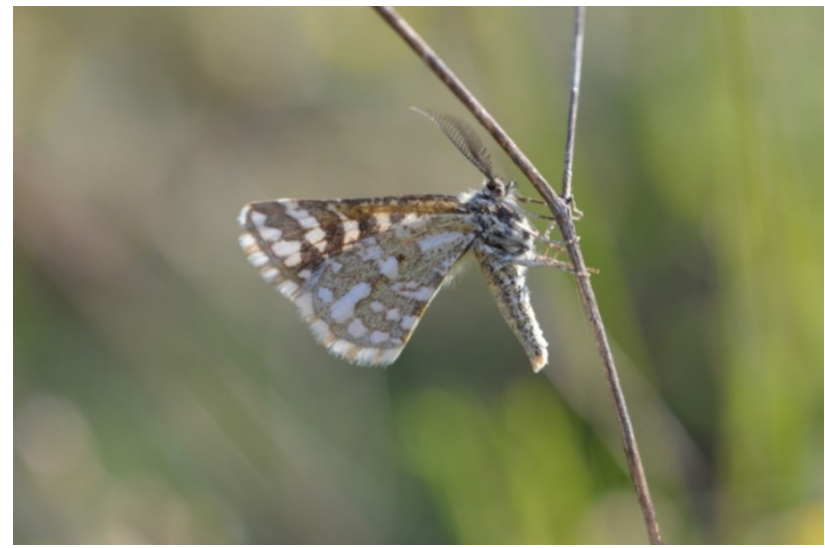

Figure 8. Narraga tessularia (Metzner, 1845), male, Bela Palanka, Šljivovički Vis. Photo Jakšić P.

7671 Apocheima hispidaria ([Denis \& Schiffermüller], 1775) 
Material examined: Beograd, Zvezdara, $187 \mathrm{~m}: 1 \mathrm{~m}, 14 . \mathrm{III}$ 2017.

The larvae feed on Quercus, Salix, Carpinus, Prunus and Malus species.

7676 Lycia graecarius (Staudinger, 1861)

Material examined: Zlatibor Mt., vic. Ljubiš, 1105 m: 1 m, 2. V 2017.

Polyphagous caterpillars feed on Achillea, Laburnum, Rumex, Taraxacum, Trifolium and Centaurea species. The presence of species of the genus Lycia in Serbia has not been completely resolved. This genus is present in Europe with eight species. In Serbia, four species are registered: L. hirtaria (Clerck, 1759), L. graecarius (Staudinger, 1861), L. zonaria (Denis und Schiffermüller, 1775) and L. pomonaria (Hübner, 1790) (Tomić et al., 2002; Stojanović et al., 2006; Jakšić, 2016a). However, the species of this genus due to insufficient morphological-anatomical distinction, as well as due to hybridization, are of particular interest (Harrison, 1919). Preliminary results of the current DNA barcoding method show that this method can solve complex taxonomic problems (Hausmann et al., 2011).

7699 Erannis defoliaria (Clerck, 1759)

A survey of the literature: Jovanović (1888). After Jovanović's first contributions there are another 35 literature data for presence of this species in Serbia (see distribution map on Fig. 9).

Material examined: Novo Brdo, Bostane, $800 \mathrm{~m}$ : common, 27. XI 1982.; Novi Beograd, vic. TC "Ušće", 1 f, 26. XI 2016. Jakšić P. photo (Fig. 10), observed and col.

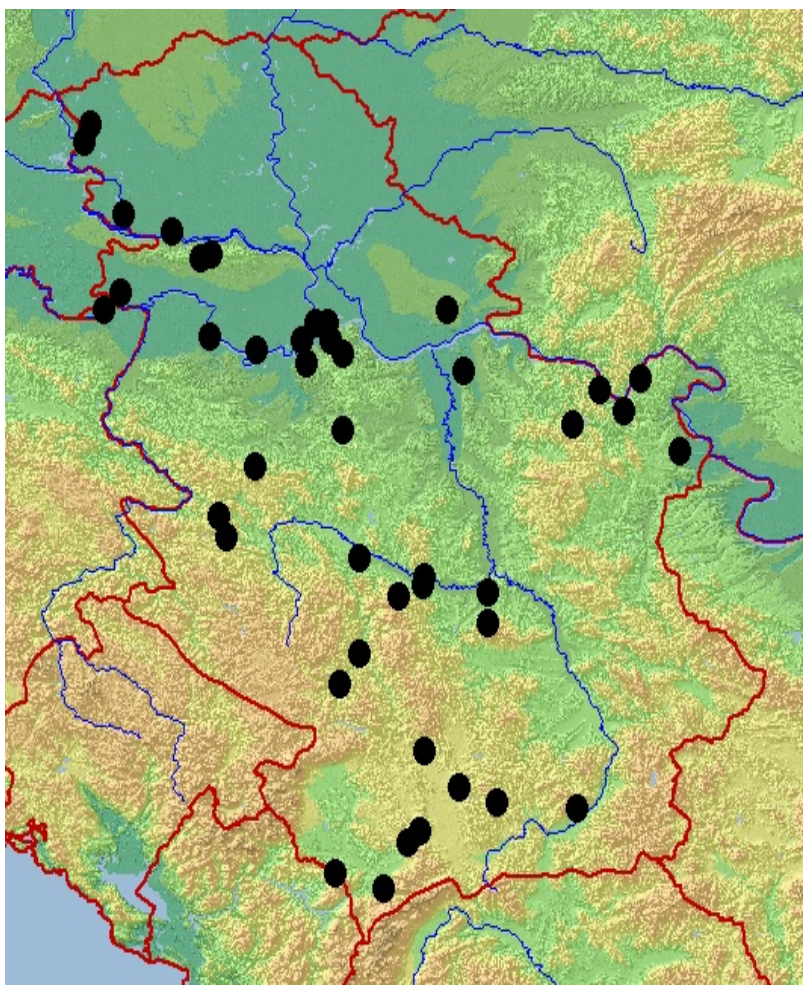

Figure 9. Erannis defoliaria (Clerck, 1759) distribution map in Serbia.

7822 Bupalus piniarius (Linnaeus, 1758)

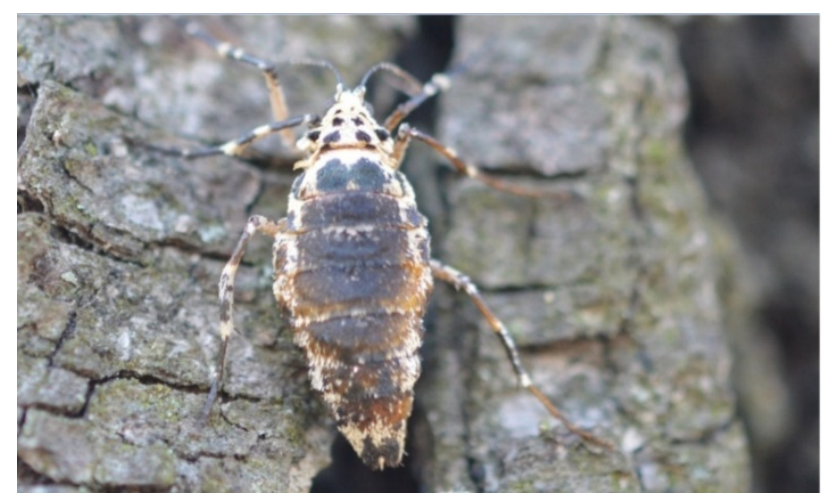

Figure 10. Erannis defoliaria (Clerck, 1759), female. Photo Jakšić P.

A survey of the Literature: Species as pests in forestry were introduced early in professional literature (Todorović, 1900), but they were just Zečević \& Radovanović (1974) gave the first faunistic data about it.

Material examined: Divčibare, vic. Kaona, 820 m: 14. VI 2017., 1 m, observed and photo (Fig. 11) by Jakšić P.

This species is an inhabitant of coniferous woodland, their caterpillar feed mainly on Pinus species.

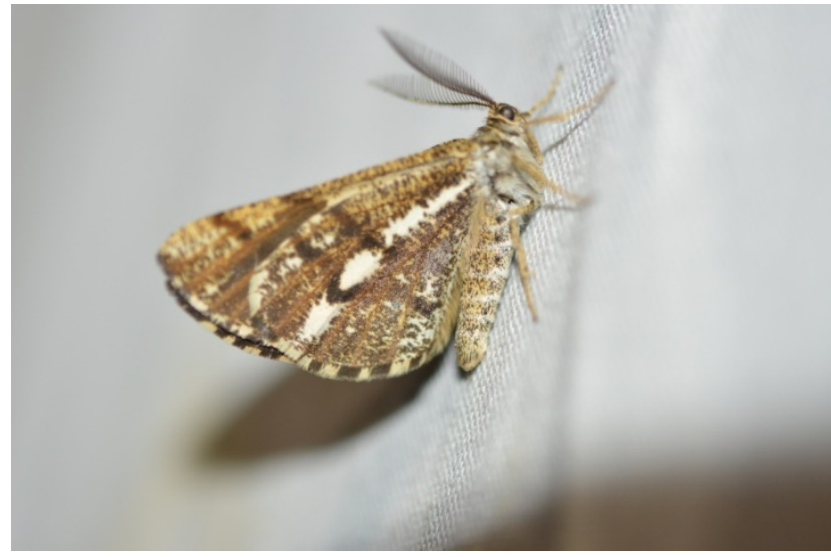

Figure 11. Bupalus piniarius (Linnaeus, 1758), male. Photo Jakšić P.

8036 Scopula immorata (Linnaeus, 1758)

Material examined: Beograd, Zvezdara, $187 \mathrm{~m}: 1 \mathrm{~m}, 28 . \mathrm{V}$ 2017.

The caterpillar feeds on various low-growing plants, as Thymus and Origanum.

8102 Idaea aureolaria ([Denis \& Schiffermüller], 1775)

Material examined: Svrljig, Tresibaba Mt., 700 m: 4 m, 19. VI 2017. Genitalia checked, slide SR-2919.

The caterpillars are polyphagous and have been recorded feeding on Rumex, Onobrychis, Securigera and Vicia species. 8184 Idaea aversata (Linnaeus, 1758)

Material examined: Beograd, Zvezdara, 187 m: 1 m, 4. IX 2017.

The larva feeds on a variety of plants, as Galium, Stellaria, Taraxacum and Polygonum species. 
8240 Scotopteryx mucronata (Scopoli, 1763)

Material examined: Sjenica, Trijebine, $1227 \mathrm{~m}: 1 \mathrm{~m}, 5 . \mathrm{VII}$ 2017.

Ulex sp. and Cytisus sp. are food plants for caterpillars.

8255 Xanthorhoe montanata ([Denis \& Schiffermüller], 1775)

Material examined: Sjenica, Trijebine, $1227 \mathrm{~m}: 1 \mathrm{f}, 5 . \mathrm{VII}$ 2017.

Caterpillars on Stachys, Geum and Rumex species.

8274 Epirrhoe tristata (Linnaeus, 1758)

Material examined: Sjenica, Trijebine, $1227 \mathrm{~m}: 1 \mathrm{~m}, 5$. VII

2017. Genitalia checked, slide SR-2934.

Caterpillars on Galium ssp.

8447 Operophtera brumata (Linnaeus, 1758)

Material examined: Beograd, Zvezdara, 187 m: 1 m, 17. XII 2017.

Larva feeds on Cornus, Evonimus, Fraxinus, Ulmus, Acer, Quercus ssp.

8513 Eupithecia breviculata (Donzel, 1837)

Beshkov (2017) for the first time reported this species for Serbia. Our finding is second. Material examined: Pirot, Crni Vrh, 1123 m: 1m, 20. VI 2017.

The larvae feed on Peucedanum and Pimpinella species.

Superfamily Noctuoidea Latreille, 1809

Fam. Notodontidae Stephens, 1829

8708 Furcula furcula (Clerck, 1759)

Material examined: Suva Planina Mt., Bojanine vode, 1000 m: 3 m, 19-20. VI 2017.

The host plants are Salix and Populus species.

8732 Pterostoma palpina (Clerck, 1759)

Material examined: Zlatibor Mt., vic. Ljubiš, 1105 m: $1 \mathrm{~m}$, 2. V 2017.

The host plants are Salix and Populus species.

Fam. Erebidae Leach, [1815]

Subfam. Rivulinae Grote, 1895

9008 Rivula sericealis (Scopoli, 1763)

Material examined: Beograd, Avala, $320 \mathrm{~m}: 1 \mathrm{~m}, 28 . \mathrm{V}$ 2017.

The larvae feed on Brachypodium and Molinia species.

Subfam. Lymantriinae Hampson, [1893]

10414 Leucoma salicis (Linnaeus, 1758)

Material examined: Beograd, Zvezdara, 187 m: 1 m, 29. VII 2017.

The larvae feed on Populus and Salix species.

10387 Calliteara pudibunda (Linnaeus, 1758)

Material examined: Zlatibor Mt., vic. Ljubiš, 1105 m: 1 m, 2. V 2017.

The larvae feed on Picea, Juniperus and Larix species.

\section{Subfam. Herminiinae Leach, 1815}

8845 Herminia tarsicrinalis (Knoch, 1782)

Material examined: Kovin, Dubovac, 70 m, 1 m, 9. VII 2016. Genitalia checked, slide SR-2781.

Caterpillars on Rubus fruticosus and Clematitis ssp.
Subfam. Metoponinae Herrich-Schäffer, [1851]

8965 Tyta luctuosa (Denis \& Schiffermüller, 1775)

Material examined: Beograd, Zvezdara, $187 \mathrm{~m}: 1 \mathrm{~m}, 28 . \mathrm{V}$ 2017.

Foodplant Convolvulus arvensis.

Subfam. Arctiinae Leach, [1815]

10583 Diacrisia sannio (Linnaeus, 1758)

Material examined: Beograd, Avala, $320 \mathrm{~m}: 1 \mathrm{~m}, 28 . \mathrm{V}$ 2017.; Sjenica, Trijebine, 1227 m, 1 f: 4. VII 2017.

The larvae feed on Galium, Plantago, Taraxacum, Epilobium and Urticae species.

10479 Pelosia muscerda (Hufnagel, 1766)

Material examined: Beograd, Avala Mt., 320 m, 15. VIII 2017., 1 male. Genitalia checked, slide SR-2914 (Fig. 12).

Larval food plants are algae, lichens and different plants, e. g. Taraxacum.

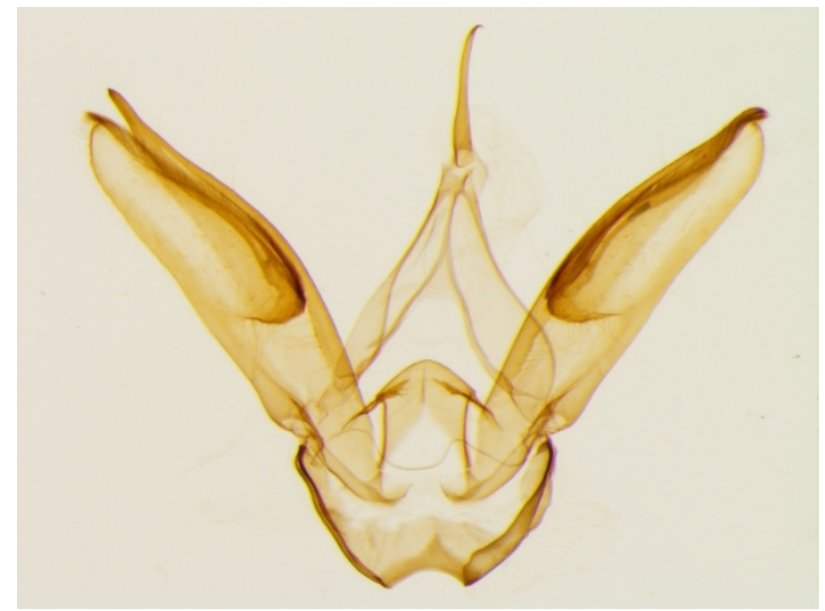

Figure 12. Pelosia muscerda (Hufnagel, 1766), male genitalia, slide SR-2914.

10499 Eilema (Wittia) sororcula (Hufnagel, 1766)

Material examined: Beograd, Zvezdara, $187 \mathrm{~m}: 1 \mathrm{~m}, 29 . \mathrm{IV}$ 2017. Genitalia checked, slide SR-2878.

Larval food plants different lichens.

10521 Dysauxes ancilla (Linnaeus, 1767)

Material examined: Kovin, Dubovac, 70 m: 1 m, 9. VII 2016. Genitalia checked, slide SR-2938 (Fig. 13).Caterpillars feed on Taraxacum, Senetio, Plantago and Lactuca species.

10526 Spiris striata (Linnaeus, 1758)

Material examined: Bela Palanka, Šljivovićki vis, 926 m: 1 f, 22. VI 2017.

Food plants of caterpillar: Artemisia, Calluna, Festuca, $\mathrm{Hi}$ eracium, Plantago, and Salvia species.

Subfam. Boletobiinae Grote, 1895

8975 Laspeyria flexula (Denis \& Schiffermüller, 1775)

Material examined: Beograd, Zvezdara, $187 \mathrm{~m}: 1 \mathrm{f}, 29 . \mathrm{V}$ 2017.

Larval food plants different Salix and Populus species. 


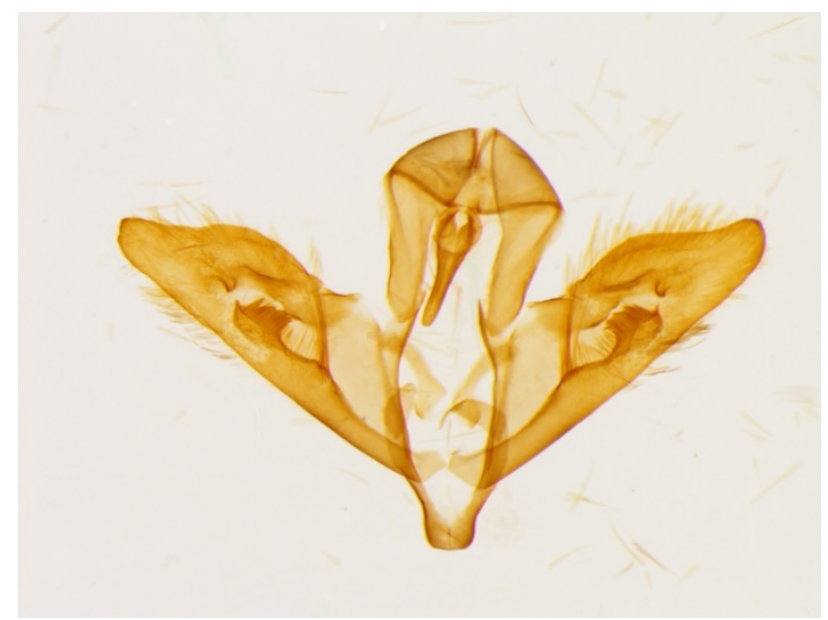

Figure 13. Dysauxes ancilla (Linnaeus, 1767), male genitalia, slide SR-2938.

Fam. Noctuidae Latreille, 1809

Subfam. Acontiinae Guenée, 1841

9097 Emmelia trabealis (Scopoli, 1763)

Material examined: Beograd, Avala, $312 \mathrm{~m}: 1 \mathrm{~m}, 7$. VII 2017.

Subfam. Oncocnemidinae Forbes Franclemont, 1954

9275 Teinoptera olivina (Herrich-Schäffer, [1852])

A survey of the literature: the first data on this species was given by Rotschild (1911) who found it on Deliblato Sands, Flamunda. Then, for Serbia, Culot (1913) also quoted it, stating that it has material in its collection. But he does not say who collected the material. Gradojević (1963) and Vasić (1969) also state this species for Deliblato Sands. Recently, Ronkay \& Ronkay (1995) describe subspecies deliblatica (G. Ronkay L. Ronkay, 1995) on material from Deliblato Sands. We can see from this review of literature that the species is known only from Deliblato Sands. Material examined: Bela Palanka, Šljivovički Vis, 926 m, 1f, 22. VI 2017. in Serbia.

This is the second locality on which this species was found

Larval food plants are Dianthus species.

Subfam. Heliothinae Boisduval, [1828]

9367 Heliotis peltigera ([Denis \& Schiffermüller], 1775)

Material examined: Beograd, Zvezdara, 187 m: 1f, 20. VIII 2017.

The larvae feed on Ononis, Senecio, Tagetes, Atropa and other species.

\section{Subfam. Bryophilinae Guenée, 1841}

8801 Cryphia algae (Fabricius, 1775)

Material examined: Beograd, Zvezdara, $187 \mathrm{~m}: 1 \mathrm{~m}, 15$. VIII

2017. Genitalia checked, slide SR-2946 (Fig. 14).

Caterpillars feed on lichen species.

8806 Bryophila ereptricula Treitschke, 1825

Material examined: Beograd, Zvezdara, 187 m: 1 f, 29. VII

2017. Genitalia checked, slide SR-2917 (Fig. 15).

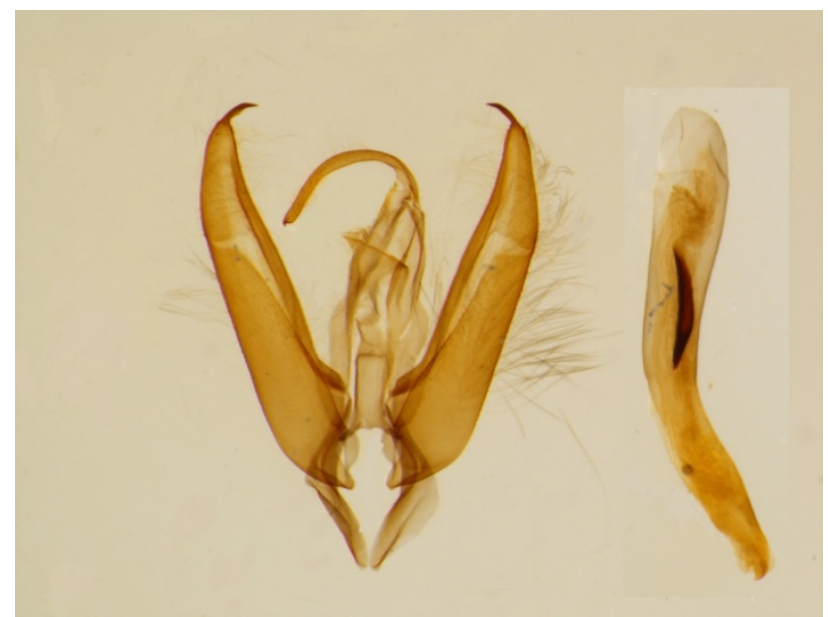

Figure 14. Cryphia algae (Fabricius, 1775), male genitalia, slide SR-2946.

Caterpillars feed on lichen and algae species.

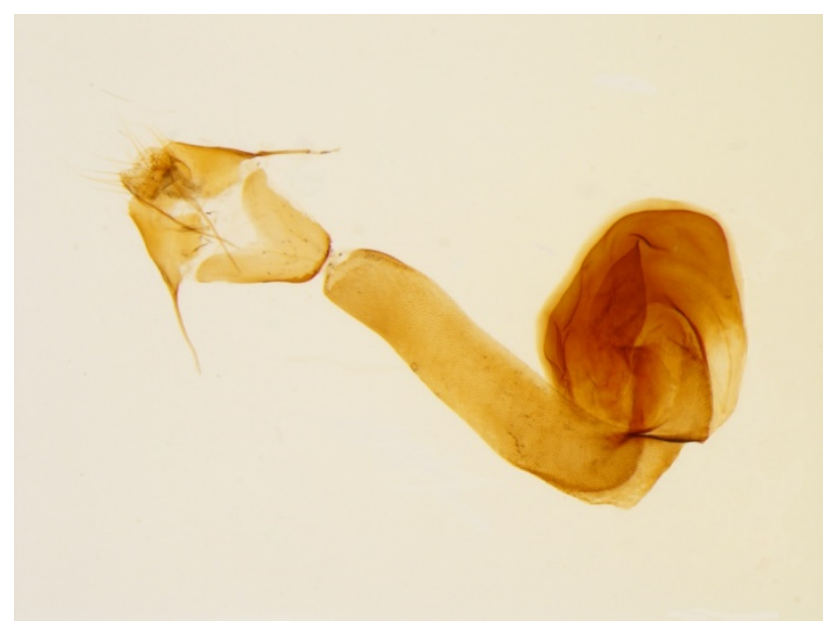

Figure 15. Bryophila ereptricula Treitschke, 1825, female genitalia, slide SR-2917.

\section{Subfam. Xyleninae Guenée, 1841}

9454 Hoplodrina ambigua ([Denis \& Schiffermüller], 1775)

Material examined: Beograd, Zvezdara, $187 \mathrm{~m}: 1 \mathrm{~m}, 24 . \mathrm{V}$ 2017., 1 f 4. IX 2017. Genitalia checked, slide SR-2947.

The polyphagous larvae feed on Betula, Medicago, Taraxacum and other species.

9492 Polyphaenis sericata (Esper, [1787])

Material examined: Kovin, Dubovac, 70 m, 1 m, 9. VII 2016. Genitalia checked, slide SR-2819.

The larvae feed on Ligustrum vulgare. 9660 Lithophane ornitopus (Hufnagel, 1766)

Material examined: Beograd, Zvezdara, 187 m: 1 m, 14. III 2017.

The caterpillars on Salix, Populus, Prunus, Ulmus, Quercus species.

Subfam. Hadeninae Guenée, 1837

10039 Orthosia cruda ([Denis \& Schiffermüller], 1775) 
Material examined: Beograd, Zvezdara, $187 \mathrm{~m}: 1 \mathrm{f}, 14 . \mathrm{III}$ 2017.

The larvae feed on a number of deciduous trees, mostly Quercus and Salix.

9895 Calocestra trifolii (Hufnagel, 1766)

Material examined: Beograd, Zvezdara, 187 m, 1 m: 4. IX 2017. Genitalia checked, slide SR-2948.

The larvae feed on Atriplex and Chenopodium species.

\section{CONCLUSIONS}

Species in Serbia are present on different types of habitats. Several species $(7671,7699,8036,8184,8447,10414,8965$, 10499, 8975, 9367, 8801, 8806, 9454, 9660, 10039 and 9895) were found in urban habitats of the city of Belgrade, with significant anthropogenic pressure, indicating ecological plasticity of these species. Some species (4743, 6604, 8845 and 10522) were found in suburban and rural habitats. These are synanthropic species, whose survival is dependent on man. The largest number of species $(4166,2231,7129,7171,7312,6478,7527,7676,7822$, 8102, 8240, 8255, 8274, 8513, 8708, 8732, 9008, 10388, 10583 , 10479,10526 and 9097) was found in typical habitats. Their occurrence is related to the presence of food for the caterpillars. In some species (7559) there was a change of habitat in relation to the typical ecological requirements of the species.

In unexplored areas, there are discovering new and rare species for Serbia's fauna. This speaks of insufficient exploration of this group of insects. Zečević (1996) summed up the knowledge for that time, quantitatively expressed by the number of 1334 species of Lepidoptera in Serbia. According to uncertificated data it is estimated that up to 2500 species have been found in Serbia so far. And that's about half the number of species known in Hungary or Romania. Our results show that, in addition to identifying new species, it is also important to identify already known species in new areas throughout Serbia.

\section{ACKNOWLEDGEMENTS}

I am thankful to Dr Stoyan Beshkov (NMNH, Sofia), Boyan Zlatkov (Institute of Biodiversity and Ecosystem Research Bulgarian Academy of Sciences) and Peder Skou (Aamosen, Denmark) for identification of some dubious species. Also, I am thankful to Ana Nahirnić to complete distribution map of Erannis defoliaria (Clerck, 1759). I am particularly grateful for the assistance given by The Insitute for Biological Research "Siniša Stanković" (IBISS), Department for Hydroecology.

\section{REFERENCES}

Aarvik, L., Bengtsson, B. , Elven, H., et al. 2017, Nordic Baltic Checklist of Lepidoptera. Norwegian Journal of Entomology, Supplement 3: 1-236.

Agenjo, R. 1956, Monografia del genero Narraga Wlk. (Lep. Geom.). Eos Revista española de entomologia, 32(1-4): pp. 7-56, pl. I-IV.
Beshkov, S. 2015, Eight new and some rare for Serbia nocturnal Lepidoptera species collected at light. Entomologist's Rec. Entomologist's Rec. J. Var., 127: pp. 212-227; 10.

Beshkov, S. 2017, Contribution to knowledge of the Lepidoptera fauna of the Balkan Peninsula. Entomologist's Rec. J. Var., 129(1); pp. 9-33; 54; 9.

Culot, J. 1913, Noctuelles et Géomètres d'Europe. In Première Partie Noctuelles.Genève. Volume II. 1-243, Pls. 1-81.

Dodok, I. 2006, The fauna of Geometridae (Lepidoptera) in the region of Užice in Western Serbia. Acta entomologica serbica: Beograd, 11(1/2); pp. 61-75.

Fibiger, M., Yela, J. L., Zilli, A., et al. 2011, Chesk list of the Quadrifid Noctuoidea of Europe. In T. Witt L. Ronkay Eds., Lymantriinae and Arctiinae including phylogeny and check list of the Quadrifid Noctuoidea of Europe. Noctuidae Europaeae.Sorø. 13: pp.23-44.

Gradojević, Z. 1963, Naselje Arthropoda travnih zajednica Deliblatske peščare i njhova sukcesija.[In Serbian]: Univerzitet u Beogradu. In Serbian; Doktorska disertacija.

Harrison, J. W. H. 1919, Studies in the hybrid bistoninae III. The stimulus of heterozygosis. Journal of Genetics, 8(4), pp. 259265. doi:10.1007/bf02983267

Hausmann, A., Haszprunar, G., \& Hebert, P. D. N. 2011, Barcoding the Geometrid Fauna of Bavaria (Lepidoptera): Successes, Surprises, and Questions. PLoS ONE, 6(2), p. 17134. doi:10.1371/journal.pone.0017134

Jakšić, P. 2016a, New contributions to the knowledge of Lepidortera fauna of Kosovo and Metohia (Republic of Serbia). The University Thought - Publication in Natural Sciences, 6(2), pp. 1-4. doi:10.5937/univtho6-12528

Jakšić, P. 2016b, Tentative check list of Serbian microlepidoptera. Ecologica Montenegrina, Podgorica, 7: pp. 33-258.

Jakšić, P. 2017, . A contribution to the knowledge of the Lepidoptera fauna of eastern Serbia. Biologica Nyssana, 8(1), pp.113-122, 8 figs.

Jovanović, D. 1888, Poljoprivredne štetočine i pomagači. Treće kolo: Štetni leptiri. Težak, XVIII(11): pp. 733-738; (12): 808-815, figs 8. Beograd. [In Serbian].

Karsholt, O. \& Razowski, J. 1996, The Lepidoptera of Europe. A Distributional Checklist.Stenstrup: Apollo Book.

Marković, M. 2014, Uticaj požara na floru planine Vidlič.Niš: Prirodno-matematički fakultet. pp. 314, 8 graf., 14 tabs., 169 figs. [In Serbian].

Plant, W. C.and Beshkov, S., Jakšić, P., \& Nahirnić, A. 2017, A contribution to knowledge of the Balkan Lepidoptera. Some Pyraloidea (Lepidoptera: Crambidae Pyralidae) encountered recently in southern Serbia, Montenegro, the Republic of Macedonia and Albania. The University Thought - Publication in Natural Sciences, 7(2), pp. 1-27. doi:10.5937/univtho7-15336

Ronkay, G. \& Ronkay, L. 1995, Cuculliinae II. Noctuidae Europaea.Sorø: Entomological press. 7; 224, 4 pl. 
Rotschild, C. 1912-1917, Adatok Magyarorszag lepkefaunajahoz / Beitrag zur Lepidopterenfauna Ungarns). Rovartani Lapok, Budapest, 1912-1917; XVI: 130-148; XVIII: 36-43; XIX: 21-29, 167-180; XX: 66-91, 170-175; XXI: 27-47, 72-77.

Rotschild, N. 1911, Adatok Magyarország lepkefaunájához. Rovartani Lapok, . XVIII(3): 36-43.

Skou, P. \& Sihvonen, P. 2015, Ennominae. In A. Hausmann Ed., The Geometrid Moths of Europe. Vol. 5. - E. J. Brill Ed., 657 pages, 16 plates with 709 colour photos, 84 plates with $288 \mathrm{~b} / \mathrm{w}$ photos; $145 \mathrm{~b} / \mathrm{w}$ illustrations, b/w distribution maps.

Stojanović, D. 2012, Taksonomsko-faunistička studija leptira (Insecta: Lepidoptera) Fruške gore.Beograd: Biološki fakultet. pp. 1-621; Disertacija.

Stojanović, D. V., Poljaković-Pajnik, L., Drekić, M., \& Vajgand, D. 2006, New findings of species zonaria (Denis und Schiffermüller, 1775) (Lepidoptera, Geometridae) for fauna of Serbia. In II International Symposium of Ecologists of Montenegro The Book of Abstracts and Programme, Kotor. pp. 45-46.

Todorović, D. 1900, Osnovi šumarstva za niže poljoprivredne škole u Srbiji.Beograd: Državna štamparija Kraljevine Srbije. In Serbian.

Tomić, D., Zečević, M., Mihajlović, L., \& Glavendekić, M. 2002, Fauna zemljomerki (Lepidoptera, Geometridae) Srbije. / Fauna of Geometrids (Lepidoptera, Geometridae) in Serbia.
In Zbornik radova o fauni Srbije.Beograd: SANU - Odeljenje hemijskih i bioloških nauka. VI: 73-164. [In Serbian, English summary].

Vajgand, D. 2012, Fauna sovica (Noctuidae, Lepidoptera) Vojvodine i parametri prognoze brojnosti / The Owlet Moths (Noctuidae, Lepidoptera) Fauna of Vojvodina and Parameters for Forecasting Abundance / Die Eulenfalterfauna (Noctuidae, Lepidoptera) der Vojvodina und die....Univerzitet u Novom Sadu Poljoprivredni fakultet. Disertacija, pp. 1-318, 2 maps, 2 figs., 180 grafs., 37 tabs. [In Serbian, English German summary].

Vasić, K. 1969, Prilog poznavanju faune sovica (Lep. Noctuidae) Deliblatskog peska. In Zbornik radova - "Deliblatski pesak" I.Beograd. 199-214.

Vasić, K. 2002, Fauna sovica (Lepidoptera, Noctuidae) Srbije / Fauna of Noctuids (Lepidoptera, Noctuidae) in Serbia. In Zbornik radova o fauni Srbije VI.Beograd: SANU - Odeljenje hemijskih i bioloških nauka. 165-293, [In Serbian, English summary].

Zečević, M. 1996, Pregled faune leptira Srbije.Beograd: Institut za istraživanja u poljoprivredi Srbija,; Beograd: IP "Nauka".

Zečević, M. \& Radovanović, S. 1974, Leptiri Timočke Krajine (makrolepidoptera).Zaječar: Zavod za poljoprivredu Zaječar / Novinska ustanova "Timok" 